\title{
Europeanization and Turkey: studying irregular migration policy
}

\section{Saime Ozcurumez \& Nazlı Şenses}

To cite this article: Saime Ozcurumez \& Nazlı Șenses (2011) Europeanization and Turkey: studying irregular migration policy, Journal of Balkan and Near Eastern Studies, 13:2, 233-248, DOI: $10.1080 / 19448953.2011 .578867$

To link to this article: https://doi.org/10.1080/19448953.2011.578867

册Published online: 20 Jun 2011.

Submit your article to this journal

III Article views: 834

Citing articles: 6 View citing articles $ک \pi$ 


\section{Europeanization and Turkey: studying irregular migration policy}

\section{SAIME OZCURUMEZ and NAZLI ŞENSES}

\section{Introduction}

This article seeks an answer to why there remain discrepancies with respect to harmonizing efforts to manage irregular migration in Europe. It does so by analysing the case of Turkey's irregular migration policy during its accession process to the European Union (EU). Turkey since the 1990s, has come to constitute a major transit and receiving country for nationals of Afghanistan, Bangladesh, Iran, Iraq, Pakistan as well as many African countries. ${ }^{1}$ At the same time, Turkey has prospects of becoming the 'new' external border of the EU. As Turkey's role as a transit and receiving country grows, issues of international migration in general, and irregular migration in particular, have become vital topics in defining the trajectory of Turkey's accession process to the EU. The EU makes recommendations on new policy directions informed by regular assessment of existing policies and administrative frameworks in Turkey in negotiations regarding initiatives that define immigration and asylum legislation. This study aims to systematically trace the development of irregular immigration policy in Turkey. It analyses how developments in each aspect of the policy are converging with EU policy priorities on irregular migration as stated in the acquis.

Informed by 'Europeanization' theories in comparative politics, this study shows how policy outcomes are shaped by the EU acting as an external pressure and 'anchor' in the irregular migration policy-making process. While we submit that policy change in this field was instigated by the EU virtually from 'scratch', we also point out that there are certain 'resistances' to certain aspects of the policy as convergence is filtered by domestic concerns. Accordingly, we argue that the extent to which Europeanization of irregular migration policy has occurred in Turkey may be classified as 'absorption with reservations'.

We believe that Turkey is a critical case in tracing the Europeanization of irregular migration policy for two reasons: first of all, as it is an accession country and full adoption of the EU acquis constitutes a powerful incentive in achieving the goal of full membership; the 'conditionality' effect is substantial in the Europeanization of Turkish policies. Secondly, because Turkey's role in the international mobility of people has changed from a sending country to a receiving country, the immigration policies of Turkey have been transforming fast in the past decade. Despite lacking a fully fledged immigration policy and

\footnotetext{
${ }^{1}$ See among others Kemal Kirişçi, 'Turkey: a country of transition from emigration to immigration', Mediterranean Politics, 12(1), 2007, pp. 91-97.
} 


\section{Saime Ozcurumez and Nazli Şenses}

law in the current period, Turkey plans to introduce substantive legislation in this policy area before the end of 2011. Under these circumstances, whereby Turkey is a newcomer to the countries of immigration laws/foreigners acts, the EU holds immense potential for impacting the course and content of such policies from inception onwards. Following that, an analysis and understanding of how Turkish irregular migration policies are converging, or not, with that of the EU reveals how and to what extent Europeanization may occur when 'conditionality' increases the incentive to comply.

The reason for studying the Europeanization of irregular migration policies per se in the Turkish context contributes to the related literature on migration and Europeanization in two ways. First, the burgeoning literature on Europeanization and migration which analyses the impact of the EU on migration policies and politics of member and non-member states, focuses more on asylum politics and relatively less on other types of migration such as family reunification or irregular migration. ${ }^{2}$ Second, in the scholarly literature on Turkey, irregular migration and Europeanization follow exclusive paths. The few works which attempt to address this relationship in the case of Turkey mostly cover immigration policies as a whole instead of focusing on irregular migration per se. ${ }^{3}$ However, our aim in this study is to focus on irregular migration and thereby bring together the discussions on irregular migration and Europeanization in this specific case.

This research examines the most regular and comprehensive secondary data: the EU acquis on irregular immigration, in order to identify the key areas of European-level policy; the Progress Reports on Turkey, in order to trace the process of governance of irregular immigration in terms of definition, technical capacity, institutions, management in terms of new policy tools and legislation. We also supplement the data with interviews with policy-makers and policy experts as well as reports within Turkish National Programs and the Asylum and Migration National Action Plan of Turkey. The article is organized as follows. We review the literature on irregular migration. Then, we briefly review the research on Europeanization and identify a framework for studying Europeanization and irregular migration in Turkey. Lastly, we review the definitions, technical capacity, institutions, new policy tools and emerging laws and legislation to examine to what extent the EU matters in irregular migration policy in Turkey.

\section{State of the Art on Irregular Migration}

The scholarly attention to irregular migration ${ }^{4}$ begins with a contestation on defining and classifying migrants with irregular status. Accordingly, Fargues

\footnotetext{
2 Thomas Faist and Andreas Ette, The Europeanization of National Policies and Politics of Immigration, Palgrave Macmillan, New York, 2007.

${ }^{3}$ Ahmet İçduygu, 'EU-ization matters: changes in immigration and asylum practices in Turkey', in Thomas Faist and Andreas Ette (eds), The Europeanization of National Policies and Politics of Immigration, Palgrave Macmillan, New York, 2007, pp. 201-222.

${ }^{4}$ There are various terms used to refer to irregular patterns of migration and migrants involved in this movement. These include undocumented, illegal, sans papiers. Most official terminology prefers the term 'illegal'. Most scholarly work, however, identifies this term as less than adequate as (1) there is this common understanding that only an act but not a person could be illegal; (2) the usage of 'illegal' while referring to irregular migration criminalizes a universal right to leave a country, which
} 
states that official regulations on entry, residence and access to work hold within them the definitions of who may be classified as an irregular migrant, according to all three categories, or only one, or two. ${ }^{5}$

The study of irregular migration has a multidisciplinary nature. Many studies focus on the state policies adopted towards irregular migrants, ${ }^{6}$ addressing different aspects of migrants' lives, such as their access to fundamental human rights, ${ }^{7}$ residence and work. ${ }^{8}$ Others focus on the causes of this movement such as globalization and neo-liberal policies, ${ }^{9}$ the demand for irregular migrant work, and the relationship between the informal market and irregular migration in the economies of receiving countries. ${ }^{10}$ There are also studies which focus on general attributes of irregular migratory flows by examining who migrates, through which migratory routes and how. ${ }^{11}$

Footnote 4 continued

is protected under article 13 of the Universal Declaration of Human Rights of 1948; and (3) as complementing the former reason, irregularity emerges only from the point of view of the receiving state as there is no universal right to enter a country that would symmetrically balance the right to leave a country, see Philippe Fargues, 'Work, refuge, transit: an emerging pattern of irregular immigration South and East of the Mediterranean', International Migration Review, 43(3), 2009, pp. $544-577$.

In this study we adopt the term 'irregular' in general; but we also employ the other terms interchangeably as put forward by the EU and Turkey in official documents.

5 Ibid.

${ }^{6}$ Dennis Broeders, 'The new digital borders of Europe: EU databases and the surveillance of irregular migrants', International Sociology, 22(1), 2007, pp. 71-92; Dennis Broeders and Godfried Engbersen, 'The fight against illegal migration: identification policies and immigrants' counterstrategies', American Behavioral Scientist, 50(12), 2007, pp. 1592-1609; Wayne A. Cornelius, 'Controlling "unwanted" immigration: lessons from the United States, 1993-2004', Journal of Ethnic and Migration Studies, 31(4), 2005, pp. 775-794; Thomas Spijkerboer, 'The human costs of border control', European Journal of Migration and Law, 9(1), 2007, pp. 127-139; Michael Samers, 'An emerging geopolitics of "illegal" immigration in the European Union', European Journal of Migration and Law, 6(1), 2004, pp. 27-45.

${ }^{7}$ Patrick A. Taran, 'Human rights of migrants: challenges of the new decade', International Migration, 38(6), 2001, pp. 7-51; Monika Krause, 'Undocumented migrants: an Arendtian perspective', European Journal of Political Theory, 7(3), 2008, pp. 331-348; Matthew J. Gibney, 'Outside the protection of the law: the situation of irregular migrants in Europe', Refugees Studies Centre, University of Oxford, Oxford, 2000.

${ }^{8}$ Aykan Erdemir and Ellie Vasta, 'Work strategies among Turkish immigrants in London', in Erik Berggren, Branka Likic-Brboric, Gülay Toksöz and Nicos Trimikliniotis (eds), Irregular Migration, Informal Labour and Community in Europe, Shaker, Maastricht, 2007, pp. 294-313; Leo R. Chavez, Shadowed Lives: Undocumented Immigrants in American Society, Harcourt Brace College, Orlando, 1998.

${ }^{9}$ Branka Likic-Brboric, 'Globalisation, EU enlargement and new migratory landscapes: the challenge of the informal economy and contingencies for "decent work", in Erik Berggren, Branka Likic-Brboric, Gülay Toksöz and Nicos Trimikliniotis (eds), Irregular Migration, Informal Labour and Community in Europe, Shaker, Maastricht, 2007, pp. 165-182.

${ }^{10}$ Emilio Reyneri, 'Illegal immigration and the underground economy', National Europe Centre Paper No. 66. Paper presented at the conference The Challenges of Immigration and Integration in the European Union and Australia (University of Sydney), Sydney, Australia, 18-20 February 2003; Gülay Toksöz, 'Informal labour markets and the need for migrant workers: the case of Turkey from a comparative perspective', in Erik Berggren, Branka Likic-Brboric, Gülay Toksöz and Nicos Trimikliniotis (eds), Irregular Migration, Informal Labour and Community in Europe, Shaker, Maastricht, 2007, pp. 183-198; Michael Samers, 'Invisible capitalism: political economy and regulation of undocumented immigration in France', Economy and Society, 32(4), 2003, pp. 555-583.

11 Ahmet İçduygu, 'The politics of irregular migratory flows in the Mediterranean basin: economy, mobility, and "illegality"', Mediterranean Politics, 12(2), 2007, pp. 141-161; Paola Monzini, 'Sea-border crossings: the organization of irregular migration to Italy', Mediterranean Politics, 12(2), 2007, pp. 163-184; Ilse van Liempt, 'Human smuggling: types, origins and dynamics', in Erik Berggren, Branka Likic- 
The literature on irregular migration in Turkey mostly mirrors the trends in the general academic literature on the matter. Some focus on the emergence of the problem; analyse the origins, demographics, motivations of migrants, the routes followed and strategies used to migrate to Turkey illegally. ${ }^{12}$ Others concentrate on human trafficking and smuggling through Turkey. ${ }^{13}$ Still a few examine the life situations of irregular migrants, ${ }^{14}$ and questions around the labour market in Turkey. ${ }^{15}$ Another set of studies, using mostly descriptive narrative, analyse the policies and legal documents on irregular migration depicting the actors, politics and policies. ${ }^{16}$

This study falls within the group which limits itself to examining policy process. However, it differs from the preceding works by systematically analysing what has been Europeanized in terms of Turkey's irregular migration policy. The study examines the extent to which the EU policy preferences on irregular migration are externalized by the EU itself and internalized by Turkey as an accession country.

\section{Europeanization as Vocation and the Turkish Case}

During the 1990s, research on Europeanization emphasized a 'top-down' analysis whereby the impact of European-level policy structures on the national level was prioritized. ${ }^{17}$ Many studies pursued the 'Europeanization' research agenda ${ }^{18}$ adopting a variety of definitions. Some, such as Bulmer and

Footnote 11 continued

Brboric, Gülay Toksöz and Nicos Trimikliniotis (eds), Irregular Migration, Informal Labour and Community in Europe, Shaker, Maastricht, 2007, pp. 85-94; John Salt, 'Trafficking and human smuggling: a European perspective', International Migration, 38(3), 2000, pp. 31-56.

${ }_{12}$ Ahmet İçduygu, Irregular Migration in Turkey, International Organization for Migration, Geneva, 2003; Ahmet İçduygu and Turgay Ünalan, 'Tides between Mediterranean shores: undocumented migration in the South of Europe'. Paper presented at the XXIV General Population Conference, Session: S26, 2001.

${ }^{13}$ Sema Erder and Selmin Kaşka, Irregular Migration and Trafficking in Women: The Case of Turkey, International Organization for Migration, Geneva, 2003; Ahmet İçduygu and Şule Toktaş, 'How do smuggling and trafficking operate via irregular border crossing in the Middle East? Evidence from fieldwork in Turkey', International Migration, 40(6), 2002, pp. 25-54.

${ }^{14}$ Ayşe Parla, 'Irregular workers or ethnic kin? Post 1990s labour migration from Bulgaria to Turkey', International Migration, 45(3), 2007, pp. 157-181; Leyla Gülçür and Pınar İlkkaracan, 'The "Natasha" experience: migrant sex workers from the Former Soviet Union and Eastern Europe in Turkey', Women's International Forum, 25(4), 2002, pp. 421-441.

${ }^{15}$ Toksöz, op. cit.; Ahmet İçduygu, 'The labour dimensions of irregular migration in Turkey', CARIM Research Reports 2006/5, Robert Schuman Centre for Advance Studies, European University Institute, Florence, 2006.

${ }^{16}$ Kemal Kirişçi, 'Managing irregular migration in Turkey: a political-bureaucratic perspective', CARIM Analytic and Synthetic Notes 2008/73. Irregular Migration Series Socio-Political Module, Robert Schuman Centre for Advance Studies, European University Institute, Florence, 2008; İbrahim Kaya, 'Legal aspects of irregular migration in Turkey', CARIM Analytic and Synthetic Notes 2008/73. Irregular Migration Series Legal Module, Robert Schuman Centre for Advance Studies, European University Institute, Florence, 2008; Bülent Çiçekli, 'Yasadışı göç, insan kaçakçılığı ve insan ticareti ile mücadele ve Türkiye', Polis Bilimleri Dergisi, 7(1), 2005, pp. 43-57; Bülent Çiçekli, 'Kaçak göç sorunu ve Türkiye', EGM Polis Dergisi, 4(14), 1998, pp. 65-72.

17 Andreas Ette and Thomas Faist, 'Europeanization of national policies and politics of immigration: research, questions and concepts', in Thomas Faist and Andreas Ette (eds), The Europeanization of National Policies and Politics of Immigration, Palgrave Macmillan, New York, 2007, pp. 3-31.

${ }^{18}$ Among others, see Robert Ladrech, 'Europeanization of domestic politics and institutions: the 
Burch, ${ }^{19}$ emphasized the capacity of EU-level policies to determine domestic administrative procedures. Others, such as Ladrech, highlighted the 'incremental process' accompanying Europeanization whereby '... EC political and economic dynamics become part of the organisational logic of national politics and policymaking ${ }^{\prime 20}$ In a highly cited definition, Radaelli refers to Europeanization as:

[p]rocesses of (a) construction (b) diffusion and (c) institutionalisation of formal and informal rules, procedures, policy paradigms, styles, 'ways of doing things' and shared beliefs and norms which are first defined and consolidated in the making of EU decisions and then incorporated in the logic of domestic discourse, identities, political structures and public policies. ${ }^{21}$

Bache summarizes Europeanization as, 'a redirection of policies and/or practices and/or preferences in the domestic arena towards those advanced by dominant EU level actors/institutions' ${ }^{22}$ Reflecting on enlargement, Grabbe adds that Europeanization is neither enlargement nor globalization or modernization, each of which might impact domestic change. ${ }^{23}$

In our analysis, similar to Grabbe, Europeanization refers to a process that is different from enlargement and harmonization, and globalization and modernization. ${ }^{24}$ Europeanization is considered an external factor influencing the transformation of policies in Turkey. As Turkey has been recently revising its immigration policy, and the domestic impact on policy-making such as the views of political parties, pressure groups and societal cleavage structures have not developed specifically and coherently on migration-related matters yet, Europeanization might be considered as constituting the most substantial external effect shaping the ways in which irregular migration policies are developed and toward what end.

Lavenex and Uçarer differentiate third countries according to the type of institutional affiliation they have with the EU. ${ }^{25}$ These institutional linkages are seen to determine the degree to which EU policy impacts third countries. Viewed through such a lens, Turkey's institutional affiliation is considered to be a 'preaccession association' and adaptation to the EU might be 'characterized as motivated by the conditionality linked to the prospect of eventual

Footnote 18 continued

case of France', Journal of Common Market Studies, 32(1), 1994, pp. 69-88; Maria Cowles, James Caporaso and Thomas Risse, Transforming Europe: Europeanization and Domestic Change, Cornell University Press, Ithaca, NY and London, 2001; Johan P. Olsen, 'The many faces of Europeanization', Journal of Common Market Studies, 40(5), 2002, pp. 921-952; Kevin Featherstone and Claudio M. Radaelli, The Politics of Europeanization, Oxford University Press, Oxford, 2003; Claudio M. Radaelli, 'The Europeanization of public policy', in Kevin Featherstone and Claudio M. Radaelli (eds), The Politics of Europeanization, Oxford University Press, Oxford, 2003, pp. 27-56.

${ }^{19}$ Simon Bulmer and Martin Burch, 'Organizing for Europe: Whitehall, the British state and European Union', Public Administration, 76(4), 1998, pp. 601-628.

${ }^{20}$ Ladrech, op. cit., p. 69.

${ }^{21}$ Radaelli, op. cit., p. 30.

${ }^{22}$ Ian Bache, 'Europeanization: a governance approach', University of Sheffield, Department of Politics, ESRC/UACES Series of Seminars on EBPP, Sheffield, UK, 29 November 2002, p. 7.

${ }^{23}$ Heather Grabbe, 'Europeanization goes East: power and uncertainty in the EU accession process', in Kevin Featherstone and Claudio M. Radaelli (eds), The Politics of Europeanization, Oxford University Press, Oxford, 2003, pp. 303-330.

24 Ibid.

${ }^{25}$ Lavenex and Uçarer, op. cit. 
membership' ${ }^{26}$ Thus, the accession process is the main driving force behind the effect of European-level policy process on the development of policies on irregular migration in Turkey.

In Europeanization research, there is a degree of consensus on where to look to observe the impact of Europeanization such as domestic structures (i.e. political structures, and structures of representation and cleavages), public policy (i.e. actors, policy problems, style, instruments, resources), cognitive and normative structures (i.e. discourse, norms and values, political legitimacy, identities, state traditions, policy paradigms, frames and narratives). ${ }^{27}$ We trace the Europeanization of a certain 'public policy', that is, irregular migration policy in Turkey. ${ }^{28} \mathrm{We}$ also pose two questions: (1) What could be Europeanized in terms of the policy? (2) To what extent has Europeanization occurred in that policy? ${ }^{29}$

Our research design runs parallel to those studies, focusing on Europeanization as 'causes of effects', that track down 'how a specific cause, such as European integration, has different effects (for example, on domestic politics and policy)' ${ }^{30}$ We examine what kind of effects Europeanization (the cause) has on irregular migration policies in Turkey in terms of policy definition, technical capacity, institutions, policy tools and legislation.

\section{Irregular Migration Policy in the EU and Turkey}

\section{The EU Acquis on Irregular Migration}

In the 1970s the European Commission adopted a dual approach towards irregular migration similar to the UN resolutions and ILO conventions of the time: on the one hand it aimed to prevent irregular migration, and on the other, it aimed to address abusive conditions that irregular migrants face. ${ }^{31}$ While retaining this dual approach, in the 1990s the Commission began to focus mostly on controlling borders and increasing security within the borders of the EU on matters concerning irregular migration. The focus shifted toward stopping illegal employment and combating smuggling by facilitating expulsion as well as readmission. Apart from the common visa policy, all measures related to irregular migration were handled in intergovernmental cooperation under the third pillar. However, since the transfer of the asylum and immigration policy to the Community pillar (Title IV EC) with the Treaty of Amsterdam (signed 1997; in force 1999), the management of irregular migration has been dealt with under EU competence instead of intergovernmental cooperation. ${ }^{32}$ Therefore, directives on

26 Ibid., p. 432.

${ }^{27}$ For details see Radaelli, op. cit., p. 35.

${ }^{28}$ For a discussion on how to study Europeanization and Turkey, see Thomas Diez, Apostolos Agnantopoulos and Alper Kaliber, 'File: Turkey, Europeanization and civil society: introduction', South European Society and Politics, 10(1), 2005, p. 7, pp. 1-15.

${ }^{29}$ Radaelli, op. cit.

30 Theofanis Exadaktylos and Claudio M. Radaelli, 'Research design in European studies: the case of Europeanization', Journal of Common Market Studies, 47(3), 2009, pp. 507-530.

${ }^{31}$ Ryszard Cholewinski, 'The EU Acquis on irregular migration: reinforcing security at the expense of rights', European Journal of Migration and Law, 2, 2000, pp. 361-405.

32 Ibid., p. 365. 
migration and asylum matters have become binding for all EU member states, with the exception of Denmark, and where Ireland and the UK decide on an ad hoc basis for each directive. ${ }^{33}$

The amended TEC article obliged the Council to take action within five years time on measures in relation to: asylum; refugees and displaced persons; rights and conditions of third country nationals with residence permits in one state who may reside in another; and immigration policy in general covering issues such as issuing of residence permits, family unification, entry and residence conditions. The Council can also take common measures on 'illegal immigration and illegal residence, including repatriation of illegal residents' ${ }^{34}$ Therefore, under Title IV, with articles 62 TEC and 63(3) TEC, the EU prepared the legal ground for its management of irregular migration in relation to border controls, visa policy, illegal immigration and residence, and the repatriation of illegal residents. ${ }^{35}$

Following these legal developments, the Tampere Conclusions (1999) brought in a more security-oriented agenda for managing irregular migration by emphasizing the prevention of irregular migration and punishment of those who support it. ${ }^{36}$ The European Council meeting in Seville in 2002 highlighted that the fight against illegal migration is crucial for implementing the Tampere Conclusions. Then, in 2002, the EU Council of Ministers adopted a plan which required action in the short and long term in six priority areas: visa policy; infrastructure for information exchange, cooperation and coordination (for migration management between member states); border management; police cooperation; aliens law and criminal law; return and readmission policy. The Hague Programme of 2004 also underlined these policy priorities in its new agenda. The latest development on the management of irregular migratory flows came in 2006 with a Commission Communication (COM (2006) 402). It again highlighted the major policy areas and priorities of the Union on irregular migration: cooperation with third countries on issues such as joint patrols and surveillance; further strengthening of external borders; combating human trafficking; tackling illegal employment; regularizing illegal immigrants; return policy; improved information exchange and policy evaluation. ${ }^{37}$ Adding to that, other policy areas of the EU acquis on the 'fight against illegal migration and return' include: establishing a penal framework for the supporters of irregular migration; coordinating the actions of immigration liaison officers; combating marriages of convenience; and concluding international agreements on readmission and human trafficking. ${ }^{38}$

\footnotetext{
${ }^{33}$ Peter J. van Krieken, The Consolidated Asylum and Migration Acquis, T. M. C. Asser Press, The Hague, 2004, p. 1.

${ }^{34}$ Ibid., p. 2.

${ }^{35}$ Freedom, Security and Justice, 'Wide-ranging common actions to combat illegal immigration at EU level and promote return of illegal immigrants', <http://ec.europa.eu/justice_home/fsj/immigra tion/illegal/fsj_immigration_illegal_en.htm $>$ (accessed 30 May 2010).

${ }^{36}$ Cholewinski, op. cit., p. 368.

37 This paragraph relies on the official EU website of 'Justice and Home Affairs' that is available at:<http://ec.europa.eu/justice_home/fsj/immigration/illegal/fsj_immigration_illegal_en.htm\#par t_2> (accessed 30 May 2010).

38 Acquis of the European Union: Title IV of the TEC, Part II of the TEC and Title VI of the TEU, available at:<http://ec.europa.eu/justice_home/doc_centre/intro/docs/jha_acquis_1008_en. pdf $>$ (accessed 17 December 2009).
} 
Cholewinski also argues that the EU initiatives point to a more securityoriented understanding of the substance and governance of irregular migration with a prioritized concern on external border controls, police cooperation, common penal frameworks, common measures on expulsion and return, readmission, and so on. Does Turkey's policy on irregular migration harmonize with that of the EU on policy definition, technical capacity, new administrative tools, institutions and laws?

\section{The Pieces of the Jigsaw Puzzle on Irregular Migration}

Definition of the policy problem: high Europeanization. The definition of a policy problem shapes the context within which solutions to the problem will be sought, and also identifies the actors and institutions involved in the policy process. Therefore, an analysis of the definition of irregular migration as a policy problem is likely to reveal how Turkey would attempt to tackle the problem. We argue that how the EU frames public policy about irregular migratory flows strongly influences how Turkey defines its own emerging policy regarding migration over its territory.

The 1998 Progress Report ${ }^{39}$ defines the policy problem around illegal immigration in such a way that Turkey comes out not as a final destination of illegal immigration but as a transit country, whereby its borders are crossed illegally by migrants who seek to move further towards Western European countries. The 2001 Report criticizes Turkey for not meeting the minimum standards in preventing human trafficking and for not adopting the necessary respective legislation. Thus, until 2002, we observe that Turkey is portrayed as a transit country for illegal migration that fails to adopt the necessary measures to 'fight' this problem. In the Progress Reports released between 2002 and 2009, Turkey is identified as both a transit country and a destination country. Among these, the 2003 Report adds that the flows of illegal migration had decreased as the result of intensified efforts to fight illegal immigration. Review of the Reports suggests that Turkey defined its role and its policy problem as a transit and destination country for irregular migration in line with the EU's identification. Moreover, in an overall assessment it aimed to solve the policy problem in accordance with the attending EU recommendations.

Similarly, the 2001 Turkish National Program states that in order to manage and control illegal migration flows Turkey will adopt and implement the EU acquis and practices on admission, readmission and expulsion. The 2005 Asylum and Migration National Action Plan of Turkey states that Turkey exists on a very important intersection of global and regional illegal migration routes, and important deterrent measures will be taken to prevent illegal immigration. A review of the Progress Reports and those of the policy documents emerging from Turkey suggest that Turkey did largely adopt the definition of the policy problem and mostly committed to complying with the policy tools to deal with the problem as they have been identified by the EU since 1998.

\footnotetext{
${ }^{39}$ The progress reports of Turkey are available at the official website of the European Commission, Enlargement, $<$ http://ec.europa.eu/enlargement/press_corner/key-documents/ > (accessed November 2009).
} 
Technical capacity for policy implementation: high Europeanization. A review of the Progress Reports reveals that Europeanization is at its peak in the transformation of technical capacity in this policy field in Turkey with least resistance.

The Progress Reports from 2000 onwards note significant change in Turkey in 'further strengthening of the external borders' and 'the fight against human trafficking' which is reflected in technical capacity and constitutes a high policy priority for the EU. Some of the examples are attempts at modernization of equipment such as more observation towers at the land border crossing with Iran in Ağr1. Other changes include setting up new check points, and appointing additional sea patrols, increasing the control of suspicious sea vessels, allocating 70 per cent of coast guards' resources in the Aegean and Mediterranean to the fight against illegal immigration, opening of new border gates in Izmir (sea), Sivas and Malatya (air).

Another area of significant progress on harmonization with the EU acquis in Turkey is in the EU's expectation of 'improved information exchange' between related bodies in order to better manage the policy problem. For example, from 2007 onwards the Progress Reports note advances in information exchange among the ministries of Foreign Affairs, Interior and Customs in order to better monitor border crossings. Therefore, the 'improved information exchange' sought by the EU among its member states is transferred to the Turkish policy context as a policy priority to be manifest within Turkey between related bodies. Moreover, there is an improvement in information exchange between the EU and Turkey as well since Turkey's participation in the CIREFI (Centre for Information, Discussion and Exchange on the Crossing of Frontiers and Immigration) Early Warning System and in the sending of statistical data on a regular basis.

Additionally, Turkey has made substantial progress in expanding its human resources capacity as part of an increase in technical capacity through the training of 553 officials of the Directorate General for Public Security of the Ministry of Interior regarding the identification and prevention of forged documents. Further, 600 judges and prosecutors, and 73 Ministry of Interior officials have been trained regarding issues in human trafficking since 2001.

Therefore, the developments in technical capacity suggest that there has been substantial Europeanization in this field in line with the EU's expectations and with least resistance from Turkey. Such harmony in this field is due to mainly the exigency for proceeding with these advancements, the fight against human trafficking and strengthening of borders, with Turkey identified as a transit and destination country with or without membership to the EU. Moreover, the fact that the EU supports efforts to overcome this need is viewed as an additional benefit rather than a challenge to national priorities.

Emergence of new tools for administering policy: moderate Europeanization. 'Cooperation with third countries' is a policy priority in the EU acquis as it regards irregular migration. Such effort expands the policy domain to the introduction of relatively new tools such as readmission agreements for the management of irregular migration within the EU and accession countries. A review of the Reports on the progress of Turkey's signing these agreements reveals mixed results in terms of the extent of Europeanization; there seems to be partial progress for signing agreements with other countries while Turkey maintains persistent resistance to signing an agreement with the EU. 
The initial Progress Reports of 1998 and 2000 criticize Turkey for not accepting to conclude any readmission agreements, and recommends that Turkey conclude these agreements. Therefore, while the EU requires readmission agreements as a tool for managing irregular migration, Turkey did not take any action initially. However, as of 2001, Turkey began to sign and negotiate readmission agreements within the framework of expanding 'cooperation with third countries' which suggests the beginnings of partial progress toward Europeanization. As of 2009, Turkey had signed readmission agreements with, for example, Syria (2001), Greece (2001), Kyrgyzstan (2003), Romania (2004) and Ukraine (2005). Turkey continues to negotiate readmission agreements with Iran, Pakistan, Bangladesh, India, Sri Lanka, China, Romania and Bulgaria. As well it has drafted and submitted agreements to Egypt, the Russian Federation, Belarus, Georgia, Israel, Sudan, Nigeria, Ethiopia, Morocco, Tunisia, Libya, Algeria, Jordan, Lebanon, Kazakhstan, Uzbekistan and Mongolia.

The persistent resistance to Europeanization remains in the area of signing a readmission agreement with the EU. Moreover, the 2009 Report notes no real progress for the conclusion of readmission agreements with source countries. One explanation for the resistance to a readmission agreement with the EU, as noted by some policy experts, is that there is a mismatch between what the EU aims to accomplish with signing such an agreement against what Turkey will have to endure. The domestic concern over this matter points to a worry about such an agreement resulting in a 'burden shift' to Turkey rather than a 'burden sharing'. The controversy over signing readmission agreements also reflects the complexity of the accession process and the detailed process of negotiation on the texts of the agreements. As an illustration, one of the main matters on readmission clauses revolves around whether Turkey would be expected to readmit on the basis of 'assumed' transit or 'proven' transit through its territory. The implication of this nuance is that if it is 'assumed' transit then Turkey would have to receive more migrants than it would be prepared for. However, if it is 'proven' transit then Turkey would only receive those whose transit through Turkey is substantiated and whose numbers are expected to be much lower. Such reasoning is in line with the expectation that Turkey would participate only in 'burden sharing' and not have to shoulder 'burden shift' for irregular migration.

As a result, emergence of the readmission agreements as a new policy tool and how Turkey responds to this policy priority has two implications for this study. First, Europeanization matters because most policy practitioners, civil society associations and scholars agree that readmission agreements would not have been considered a policy tool for combating irregular migration unless the EU put it on the policy agenda. Second, the progress in signing these agreements with other countries is fairly slow and mixed; with the EU specifically, progress moves at almost zero speed. This is partially a result of the credibility and commitment worries surrounding the end game of the accession process toward full membership whereby signing a readmission agreement with the EU before full membership is viewed as a burden that Turkey might then have to shoulder without membership benefits.

Institutions: moderate Europeanization. Europeanization of irregular migration policy occurs at a varying pace and to a varying extent seen in a review of the 
progress on the transformation of the institutions used for implementing the policy. While Turkey has harmonized its institutional change in accordance with most of the EU acquis, there is also some resistance to certain changes. Negotiation on border management is a critical case in point. In the 2000 Progress Report, the EU criticizes Turkey for not having a unified and civilian command over border control; and currently the command is dispersed among diverse non-civilian institutions. This criticism is repeated in later Reports as Turkey failed to comply. The 2009 Report notes that '[f]urther steps need to be taken to establish a new civilian, non-military, border law enforcement body under the Ministry of the Interior to perform border control tasks'. For over a decade, the Progress Reports highlight the need for the setting up of a certain institutional design commensurate with the EU's expectations to solve an already agreed upon policy problem. However, Turkey does not comply with this and fails to establish the civilian border control body. This begs for an explanation. We propose that this mismatch is a consequence of the divergence between Turkey's domestic policy concerns and priorities against the EU's expectations and priorities, which then breeds domestic resistance on the part of some policy actors. Policy experts also suggest that such a change is fairly difficult to implement within Turkey because border command is closely related with issues of security and terrorism, where most of the time border control is considered to be no different than border security, although these two are completely different matters. Therefore, the Europeanization of institutions for managing irregular migration has taken place in a rather slow and reluctant manner in some areas concerning the further strengthening of the external borders with civilian control. Although the EU also places an emphasis on security matters concerning irregular migration, a mismatch surfaces on how the EU frames its management with civilian control and how Turkey aims to retain additional control by security forces. Such discord results in limits to the extent of Europeanization.

In contrast to relatively strong resistance in the establishment of civilian border control, there are signs of commitment on the side of Turkey to cooperation in fighting irregular migration along the EU's expectations. The 2003 Progress Report notes that an inter-ministerial Task Force was established that works under the coordination of the Ministry of Foreign Affairs and is responsible for the fight against human trafficking. Following that the 2004 Progress Report states that a ministerial decision was issued concerning the establishment of a 'Projects Directorate for Integrated Border Management' under the Ministry of Interior. The 2008 Report highlights the formation of a high-level working group responsible for increasing closer inter-agency cooperation on border tasks in relation to irregular immigration. The 2009 Progress Report highlights the efforts on the part of Turkey to conclude working arrangements with FRONTEX. One explanation for progress in these fields is that such initiatives do not imply major institutional transformation and constitute gradual steps for forming platforms of discussion and cooperation addressing different dimensions of irregular migration policy. Moreover, these initiatives do not require a major re-allocation of national administrative and financial resources, or a re-definition of policy priorities.

Europeanization of institutions beyond border management includes the efforts concerning combating illegal migration as well as improved facilities for return and readmission processes. Accordingly, the 2003 Turkish National 


\section{Saime Ozcurumez and Nazli Şenses}

Program and the 2005 Asylum and Migration National Action Plan emphasize the need for the establishment of removal centres. By 2006 and 2008, the Progress Reports note the establishment of special shelters for the victims of human trafficking in Istanbul and Ankara, where medical, psychological and legal counselling are provided. Moreover, the Ministry of Interior works on the establishment of these centres together with Britain, Greece and Holland in an EU Twinning Project, which is entitled 'Support to Turkey's Capacity in Combating Illegal Immigration and Establishment of Removal Centres for Illegal Migrants', and with financial support from EU funds to complete the project by $2011 .^{40}$ As an effective part of return policy, the efforts to establish removal centres constitute a major attempt to comply with the requirements of the EU acquis. These efforts proceed with relatively more ease since there is a substantial match between the EU's and Turkey's priorities for the return of the existing irregular migrants and combating human trafficking. Moreover, they commit funds and know-how in a joint manner with the member states which also facilitates Turkey's efforts for harmonization.

Therefore, major efforts are made to expand the existing institutions and introduce new institutions for harmonizing with the EU acquis in the accession process signalling that Europeanization matters. However, the ensuing criticism in the Progress Reports over matters of civilian border control or the 2009 Progress Report criticism on the capacity of Turkey to accommodate illegal migrants despite the recently introduced centres in Bitlis and Adana suggests that there is variation in the extent and speed of Europeanization. The moderate Europeanization in the institutional transformation may be attributed to the mismatch over policy ideas (border control vs. border security) and the contention over which actors (civilian officers vs. security forces) should be in charge when the EU's and Turkey's preferences are compared.

Laws and legislation governing irregular migration: (potentially) very high Europeanization. To date, Turkey lacks a single and specific legislation governing migration in general and irregular migration in particular. Multiple laws and regulations govern this area, for example, the Passport Law, Law on the Work Permit for Foreigners. The Progress Reports from 2001 onwards reveal that there is substantial Europeanization in this field, with least resistance, similar to the definition of the policy problem and technical capacity. However, the reason for the least resistance is not necessarily about convergence over exigency, rather, the void in the legislative framework in this area suggests EU input for formulating legislation from 'scratch' in certain areas.

The willingness for Europeanization and also the lack of resistance is revealed in various instances. In the 2001 and the 2002 Reports Turkey is criticized for not ratifying the international instruments of combating illegal immigration, the 2000 UN Convention against Transnational Organized Crime (Palermo Convention), its Protocol to Prevent, Suppress, and Punish Trafficking in Persons, Especially Women and Children and its Protocol Against the Smuggling of Migrants by Land, Sea and Air. The Turkish National Program of 2001 immediately states that

\footnotetext{
40 'Yasadışı göçe 5 yıldızlı tesis', Aksam gazetesi,<http://www.aksam.com.tr/2009/05/24/haber/ siyaset/2017/yasadisi_goce_5_yildizli_tesis.html> (accessed 30 September 2009). ‘Güvenlik hizmetlerinde AB'e uyum kriterleri', $A B H A B E R,<$ http://www.abhaber.com/yazdir.php? $\mathrm{id}=23177>($ accessed 30 September 2009).
} 
Turkey aims to ratify these protocols; the Palermo Convention and its Protocols were actually ratified in 2003. The National Program also states that Turkey should amend a number of laws such as the Law on the Residence and Travel of Foreigners and Passport Law, Law on the Protection and Security of the Land Borders in order to align with the EU acquis. Additionally, the Program sets the goal of aligning the Foreigners Draft Law on matters concerning the format of issued residence permits, counterfeit marriages and also aligning Deportation Regulation with the related European Council decisions. Concerning human trafficking, it is stated that Turkey will take necessary measures to adopt and implement the EU legislation on that matter as well.

Concerning the extent to which these goals were achieved, that is legislation was Europeanized, the 2003 Progress Report states that Turkey has adopted a new law on work permits for foreigners. The law envisaged a centralized system for granting work permits and, as a significant improvement, it allowed foreigners to be employed as domestic workers. Also, the Law on Turkish Nationality was amended in order to prevent marriages of convenience. The Turkish Penal Code was amended in 2002 to align with the 2000 UN Convention and its protocols. The amendments were related to prohibiting human trafficking and prescribed heavy penalties. Additionally, concerning trafficking of human beings, Turkey adopted a directive which secures the right of free medical treatment for the victims of trafficking. Also, governorships were authorized to extend temporary residence permits up to six months for the victims. In order to prevent trafficking and smuggling activities, a new Road Transportation Law and regulation was adopted; relatedly, articles of the Turkish Penal Code (79-80) increased the penalties for these criminal activities in 2005 as highlighted in the 2005 Progress Report. The 2008 Report states that the Witness Protection Law, which protects the identity of victims who decide to give testimony against the perpetrators of trafficking activities, was entered into force.

Moreover, the Foreigners Law will be aligned with the European Council Recommendation on the prevention of illegal migration and work, and improvement of the capacity to control illegal migration. This legislation is expected to be adopted between 2009 and 2013. Currently technical work is going on under the responsibility of the Ministry of Interior and Foreign Affairs. ${ }^{41}$ Moreover, the Passport Law will be amended for structuring the airport transit visa in order to attain border security and contribute to the prevention of illegal entries. This legislative amendment is also under consideration in Parliament and expected to be passed between 2009 and $2013 .^{42}$

Therefore, in terms of the Europeanization of laws and legislation on irregular migration, Turkey has made substantial efforts to fully align with the EU acquis progressively and so far no clear resistance can be identified in this field. Such a finding has implications for this study. First, this ease of progress is partly due to the lack of any substantial and centralized pre-existing national legislation which might be challenged. Second, to date most of the progress is taking place through technocratic and academic routes rather than through the debate of political

\footnotetext{
${ }^{41}$ ABGS, 'Türkiye'nin AB Müktesebatına Uyum Programı, (2007-2013)', 24-Adalet, Özgürlük ve Güvenlik, <http://www.abgs.gov.tr/files/Muktesebat_Uyum_Programi/24_AdaletOzgurl ukveGuvenlik.pdf $>$ (accessed 15 October 2009).

${ }^{42}$ Ibid.
} 
actors therefore mostly following an assessment of needs and a discussion of best practices for the choice over signing agreements as well as adopting legislation.

\section{'Absorption with Reservation?'}

This study confirms certain findings of most of the scholars of migration studying Turkey in that the EU does matter more than domestic policy initiatives. ${ }^{43}$ It advances the literature by refining the conclusions along the lines of identifying change in different aspects of the same policy area, examining degrees of Europeanization (high, moderate, low) for these different aspects, and discussing the reasons for this variation. How do the approach and findings in our study fit with the Europeanization literature?

We argue that when we adopt the terminology from the Europeanization literature the Europeanization of irregular migration policy in Turkey may be dubbed as 'absorption with reservation'. Such a depiction originates from Radaelli's scale of retrenchment, inertia, absorption and transformation. ${ }^{44}$ In the case of Turkey, despite substantial developments in the field of irregular migration, we maintain that there is 'absorption', which is the adjustment to and adaptation of European 'ways of doing things' but 'without real modification of the essential structures and changes in the "logic" of political behaviour', 4 however, 'with reservation'. In this way, we acknowledge the transformation in this policy area and also the change in the 'essential structures' more so than Radaelli's 'absorption' characterization. However, we also would like to note that 'absorption with reservation' is short of 'transformation', which implies substantial change. The main reason for this assertion is that Turkey lacked a coherent and comprehensive policy towards irregular migration before the matter became part of the EU accession process. Therefore, perhaps there is room for considering the irregular migration policy in Turkey as having been transformed with respect to Radaelli's scale. However, despite the void, on some pertinent policy items Turkey refrains from moving forward when the EU acquis is at odds with domestic ways of framing and implementing policies or identifying policy priorities based on national interest. This is precisely the case with respect to signing a readmission agreement with the EU and the establishment of a single and civilian border control command. Therefore, Europeanization goes through the filter of domestic priorities, actors and interests. We identify this as 'absorption' because Turkey makes substantial attempts to harmonize with the EU acquis in different fields of irregular migration. However, the extent and pace of that harmonization depends on domestic priorities. We classify such domestic concerns as, not implying complete and irreversible resistance however suggesting a qualified signal for future harmonization with the EU scheme while asserting national interest in

\footnotetext{
${ }^{43}$ See Ahmet İçduygu, Irregular Migration in Turkey, International Organization for Migration, Geneva, 2003, p. 56.

${ }^{44}$ See Radaelli, op. cit., p. 38. Inertia is when there is no change, that is, no Europeanization of public policy. Retrenchment signifies a turn away from European 'ways of doing things'. Transformation causes a 'paradigmatic change' in which 'the fundamental logic of political behaviour changes'.

${ }^{45}$ Ibid.
} 
contested areas in the current negotiations; therefore, here, 'absorption' warrants the caveat 'with reservation'.

\section{Conclusion}

This study discusses transformation in the context of policy on irregular migration in the case of Turkey. It reviews the impact of Europeanization by answering two questions: (1) what has been Europeanized in terms of irregular migration policy; (2) what is the extent of Europeanization? We base our analysis on Progress Reports and Turkish National Programs and also on supplementary interviews with policy experts. Our analysis indicates that Europeanization occurs in five policy aspects identified in the study albeit at different speeds and to different extents. We note that domestic concerns and priorities constitute the main reason that European priorities do not completely define the emerging policy, for example, in civilian border management and the readmission agreement between the EU and Turkey.

This study advances the existing literature by providing an empirically detailed account of how and through which channels Europeanization occurs and how certain matters are refracted by domestic concerns. We conclude that Europeanization takes place in the form of 'absorption with reservation'. Three policy aspects (definition of the policy problem, technical capacity and laws and legislation on the policy) provide indicators of high Europeanization albeit at different speeds. However, two other areas (institutions and new policy tools) indicate moderate levels of Europeanization and low speed. We note that Europeanization staggers in these two areas due to domestic concerns and structural reasons inherited from the ambiguity inherent in the EU-Turkey accession process. First, if the EU preferences challenge an existing domestic priority and policy item, then EU preferences will be refracted. For example, introducing a civilian border control administration is a high priority for the EU; however, viewed from Turkey, such a transformation challenges how Turkey conceptualizes border security and administers it in line with concerns over national security. In other words, border control mechanisms are also part of counter-terrorism plans and measures which some experts consider requiring administration beyond civilian control. Second, Europeanization walks on shaky ground on the theme of negotiations between Turkey and the EU on readmission agreements. In this case, the scepticism over prospects of EU membership intervenes. There is substantial concern on the part of policymakers and experts that a readmission agreement would shift the burden of challenges of irregular migration policies of the EU onto Turkish territory without any credible 'promise' of membership. Therefore, there are both intrinsic and structural reasons why Europeanization in irregular migration takes place at different paces. In the former case of civilian border control, the Turkish logic of border management contradicts to some extent the EU logic of border management. In the latter case, the structural challenge is overshadowed by membership prospects and hampers the readmission agreements because of the accession process itself. Also there is a credibility and confidence crisis between Turkey and the EU in this process. Therefore, we characterize the Europeanization in this policy area as 'absorption with reservation'. In other words, we 
characterize Europeanization in this field as moving beyond absorption however remaining less than total transformation (the transfer of all the EU acquis as is).

The conclusions of this study corroborate the findings in the general literature which suggest that the EU accession negotiations constitute a major impetus for any substantial attempt for change in the field of irregular migration. However, this study claims that the extent and speed of Europeanization vary for different components of this policy field even when not (yet) subjected to the scrutiny of political actors.

Saime Ozcurumez is Assistant Professor in the Department of Political Science at Bilkent University. Her research interests are comparative politics, European politics, immigration law and policy, social movements, European Union studies, comparative health policy and politics.

Address for correspondence: Department of Political Science, Bilkent University, 06800 Bilkent, Ankara, Turkey. E-mail: saime@bilkent.edu.tr

Nazlı Şenses is a PhD candidate in the Department of Political Science at Bilkent University. Her research interests are comparative politics, immigration policies and Europeanization. She works on a comparative study of irregular immigration policies in Greece, Spain and Turkey.

Address for correspondence: Department of Political Science, Bilkent University, 06800 Bilkent, Ankara, Turkey. E-mail: senses@bilkent.edu.tr 